\title{
ON DEMAND WATER SUPPLY AND WATER USE EFFICIENCY THROUGH BURRIED PIPE SYSTEM- A CASE STUDY
}

\author{
Radhakrishna A. $\mathbf{R}^{1}$ and Ravikumar A. $S^{2}$ \\ ${ }^{1}$ Assistant Professor, Department of Agricultural Engineering, GKVK, UAS Bangalore, Karnataka, India \\ ${ }^{2}$ Associate Professor, Department of Civil Engineering, UVCE, Bangalore University, Bangalore, Karnataka, India
}

\begin{abstract}
Land and water are the two basic needs of agricultural and economic development of any country. According to FAO, about 60 percent of water supplied in surface irrigation course goes unused. Majority of irrigation projects undertaken worldwide indicated that generally low irrigation efficiencies. The main component of water losses in irrigation system may be attributed to water losses in storage, losses in conveyance system, losses in operations and losses in application. Indiscriminate use of water indirectly affects the normal growth and yield of the crop. To strengthen the sustainable agriculture in Karnataka, tank irrigation system was established centuries ago. During the past few decades, due to erratic rainfall and distribution pattern during kharif, the tank filling status was not consistent and probability of available water for irrigation purposes was also not certain. In order to minimize the losses in conveyance of water from the source to the target site, the buried pipe Distributary systems have been designed and developed, which is the first of its kind for tank command irrigation with the adoption of solar pump to lift water from the jack well in order to reduce the dependence on the erratic electric supply at village level. The effect of on-demand water supply on different crops yield during Kharif and rabi/summer 2003 to 2008 indicated that there was a significant change in the yield of crops and cropping pattern in command area due to intervention of on demand water supply.
\end{abstract}

Keywords: Command area, crop water requirement, buried pipe system, water use efficiency

\section{INTRODUCTION}

In the command area, improper management of irrigation water not only leads to wastage of water but also land degradation. Under these conditions, too shortcomings of surface irrigation systems becomes more important, firstly, a high proportion of water is lost between the source and crop, and secondly deliveries of water to individual farmers are not optimum in quality or timing or reliability. The extent of these shortcomings depends on the physical infrastructure and management of the system, and its particular environment. The awareness of various options available to tackle these problems and achieve better performance from surface irrigation systems, include lined canals to reduce losses, control structures and systematic management to improve deliveries and demand type systems to enable farmers to control their own water supplies.

Though the farmers could get sufficient water for irrigation purposes from bore wells, they have totally failed in proper utilization of the same. Application of large quantities of water for paddy cultivation maintaining 5 to $7.5 \mathrm{~cm}$ of water in paddy fields and excess application of water more than the crop requirement through surface irrigation methods for others crops has led to severe ground water exploitation. Due to excessive exploitation the ground water level has gone down. Usage of auto starters and single phase switches to remove as much water as possible has further worsened the situation.
Lack of knowledge about critical stages of crop growth for irrigation, effective root zone, field capacity of the soil, appropriate and crop specific irrigation methods contributed much towards not only wastage of water but also decreased crop yields. Under such a situation in order to create awareness among the farmers about the importance of irrigation water and bring changes in the cropping pattern from high water consumptive crops like submerged paddy to low water consumptive and high yielding and high value crops like vegetables along with commercial crops like mulberry,

The water table is gradually declining in several part of the country, efficient use of available water has become extremely important and it is in this context the efficient irrigation system have a vital role. Maintaining the ground water level and to have a check on ground water exploitation and, as such the command area needs improvements for continuous use of tank water to promote irrigated agriculture system (Chowdegowda, 2003).

Alternative technology is the underground pipeline system to avoid conveyance losses for surface irrigation in the tank command area. This offers improvements over conventional surface irrigation system with canals. It will be more efficient and more flexible in operation than conventional canal system, with fewer environmental problems. At present, knowledge of soil-moisture-plant relations permits irrigation systems to be 
designed for applying water in required quantities when needed. Irrigation water could be applied at rates to suit the infiltration rates of soils and thereby obtain maximum efficiency in water use and prevent deterioration of land quality. The advanced irrigation systems were introduced into the command area to evaluate the effect of the irrigation systems on crop yields and water use efficiency. In view of the above, an attempt has been made in the present study with ondemand water supply through buried pipe system for efficient irrigation for Chunchadenahalli tank, Kolar district.

\section{DETAILS OF STUDY AREA}

The study area chosen for the present study was Chunchadenahalli tank, Kolar district. Kolar district is one of the drought affected districts in Karnataka and has more number of irrigation tanks (Raju et al., 2003). Chunchadenahalli tank is situated adjacent to Chunchadenahalli village, Vakkaleri hobli, Kolar taluk, Kolar district. Fig. 1 shows the catchment and command area of Chunchadenahalli tank. The catchment and command area of the tank geographically lies between 130 o 40 " and 13 o 8' 15 " N latitude and 78o 1'30" and 78o 4' 5" E longitude. The tank is covered in Survey of India Toposheet No. $57 \mathrm{~K} / 4$ on $1: 50,000$ scale. Hydrogeologically the tank watershed area is situated in granite gneiss and it is moderately weathered. Large area of the catchment is hilly with red sandy loam soil and the depth of the soil varies from 7.5 to $22.5 \mathrm{~cm}$.

The Chunchadenahalli tank has an independent catchment area of 544 ha and water spread area of 12.5 ha. The command area contains 23.37 ha, which is owned by 75 farmers. The total length of the tank bund is $776.84 \mathrm{~m}$. There were five main irrigation channels and ten sub channels. The total volume of water in the tank at full tank level was found to be 158210.85 $\mathrm{m} 3$ where as it was $244353.81 \mathrm{~m} 3$ at maximum water level.

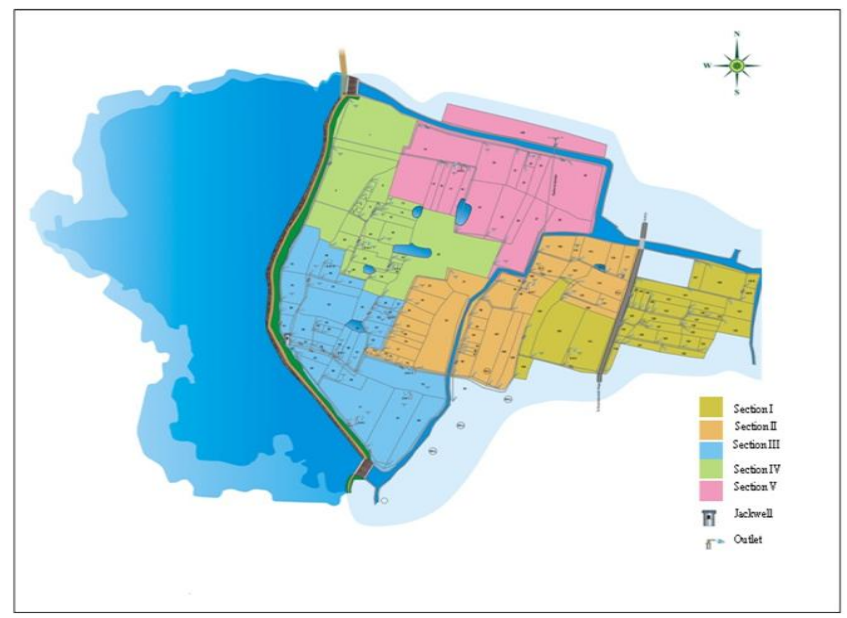

Fig -1: Catchment and command area of Chunchdenahalli tank
The total rainfall recorded during the years 2003 to 2008 varies from 462.2 to $1188.1 \mathrm{~mm}$. The highest rainfall of $1188.1 \mathrm{~mm}$ was received during 2004. The water discharges from the bore wells in command area have shown that, the bore wells water yield was highest during 2004 to 2006 by recording 3.68 to 4.54 1/sec.

\section{METHODOLOGY}

\subsection{Design of Buried Pipe Distributary System}

The main advantages of buried pipe line system are saving of land, elimination of seepage losses, and relatively little maintenance. The efforts made on implementation of buried pipeline system had led to reduction in water consumption for paddy and encouraged high value crops in the command area. In supportive to present study, Campbell (1984) reported that pipe systems in northern India assured flow delivery at the design discharge to the furthest irrigator with a minimum losses and unauthorized diversions en route. Adoption of buried pipeline distributary systems had lead to the reduction in water transit and distribution losses, reduction in the land area taken up by the distribution system and reduction in the maintenance and operating costs of the irrigation system. Murthy (2002) also opined that buried pipe line systems were used for conveying irrigation water on the farm worked efficiently.

The entire command area of the tank was divided into five sections so that water can be given to each section once in five days and also to reduce the cost of pipe system considering 148 existing plots consisting of 65 farmers in the command area. The salient features of the command area and the existing land profile, the main channels and sub channels were considered while designing the buried pipeline system.

The information on the outlets of buried pipe system for individual plots has been considered and the rate of water discharge in the pipe system for individual plot has been worked out. The buried pipe distributary system was designed based on the rate of water discharge in the pipe system for individual plots, crop water demand of the command area and cropping pattern. The friction losses in the pipe were estimated by Hazen-Williams equation. The rate of discharge and friction loss in section I to $\mathrm{V}$ of command area are presented in Table 1.The maximum head of $18.00 \mathrm{~m}$ in section I and maximum discharge of 7.16 were considered for the designing of buried pipe system. Depending upon the discharge in each section and the designed diameter such as 40 $\mathrm{mm}, 50 \mathrm{~mm}, 63 \mathrm{~mm}, 75 \mathrm{~mm}$ and $90 \mathrm{~mm}$, which are of standard diameters available in the market with $6 \mathrm{~kg} / \mathrm{cm}^{2}$ and $4 \mathrm{~kg} / \mathrm{cm}^{2}$ pressure class of IS-4985 have been considered as buried pipe system. 


\subsection{Conveyance Efficiency of Buried Pipe System and}

\section{Open Channel}

The data on the conveyance efficiency of open channel and buried pipe system (Table 2) revealed that the conveyance efficiency of water was comparatively highest in buried pipe system compared to open channel by recording 93 to 97 per cent and 55 to 72 percent respectively. The findings of the present investigation are in agreement with the results of Campbell (1984). Murthy (2002) also stated the use of underground pipe line system (also known as buried pipelines) for conveying irrigation water on the farm for effective irrigation. The main advantages of the buried pipe line irrigation systems are saving of land and water, elimination of seepage losses and relatively little maintenance cost.

Table -1: Details of discharge and head loss

\begin{tabular}{|c|c|c|c|c|c|c|}
\hline $\begin{array}{l}\dot{z} \\
\dot{n}\end{array}$ & Item & 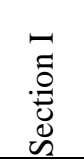 & 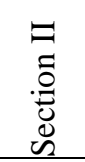 & $\begin{array}{l}\Xi \\
\Xi \\
.0 \\
.0 \\
\tilde{D} \\
\text { Un }\end{array}$ & 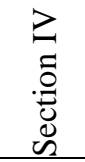 & 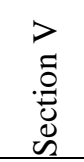 \\
\hline 1 & Discharge $(1 / \mathrm{s})$ & 6.96 & 7.16 & 7.07 & 6.25 & 6.55 \\
\hline 2 & Frictional head (m) & 14 & 11 & 4 & 9 & 12 \\
\hline 3 & Suction head (m) & 3 & 3 & 3 & 3 & 3 \\
\hline 4 & Fitting losses (m) & 2 & 2 & 2 & 2 & 2 \\
\hline 5 & Head gain $(\mathrm{m})$ & -1 & -1 & -1 & -1 & -1 \\
\hline & Total head (m) & 18 & 15 & 8 & 13 & 16 \\
\hline
\end{tabular}

\subsection{Effect of on Demand Water Supply System and} Efficient Irrigation Water Use Efficiency

On-demand water supply system and efficient Irrigation (Table 3) has shown significant change in WUE in Chunchadenahalli tank command area (2003-04 to 2007-08). During 2003 kharif, the WUE of $18.5 \mathrm{~kg} / \mathrm{ha} . \mathrm{cm}$ and 13.0 $\mathrm{kg} / \mathrm{ha} \mathrm{cm}$ in paddy and mulberry, respectively. However, during 2007 the WUE was 88.12 and $39 \mathrm{~kg} / \mathrm{ha}$. cm in paddy and mulberry, respectively. During 2004, the WUE of paddy $20.5 \mathrm{~kg} / \mathrm{ha}$. cm followed by cauliflower $(625 \mathrm{~kg} / \mathrm{ha} \mathrm{cm})$. While WUE of paddy $30.7 \mathrm{~kg} / \mathrm{ha} \mathrm{cm}$ during 2005 (approximately 50 per cent more), cabbage $1661 \mathrm{~kg} / \mathrm{ha} . \mathrm{cm}$. During 2006, tomato yield with a WUE of $1857 \mathrm{~kg} / \mathrm{ha} . \mathrm{cm}$ followed by cauliflower WUE of $2250 \mathrm{~kg} / \mathrm{ha} . \mathrm{cm}$ and capsicum $625 \mathrm{~kg} / \mathrm{ha} . \mathrm{cm}$, respectively. During 2007, tomato yield with WUE $1089 \mathrm{~kg} / \mathrm{ha}$. cm followed by cauliflower, coriander, red gram (vegetable), field beans with WUE of $2034,1600,239.0$ and $250 \mathrm{~kg} / \mathrm{ha}$. cm respectively

The water use efficiency was worked out for all the crops based on the total water consumed and the yield obtained during kharif 2007. The paddy crop grown under SRI (on and off) method of paddy cultivation on an average consumed about 86.6 ha.cm of water with a water use efficiency of 80.6 $\mathrm{kg} / \mathrm{ha} . \mathrm{cm}$. While transplanted ragi crop recorded on an average of 31.7 ha.cm, with a water use efficiency of $110 \mathrm{~kg} / \mathrm{ha.cm}$, the rainfed ragi with 24.2 ha.cm of water with a WUE of 97.7 $\mathrm{q} / \mathrm{ha} . \mathrm{cm}$. The difference in WUE in case of rainfed and transplanted ragi may be attributed to protective irrigation during critical stages of crop growth and whenever there was long dry spells in between the two rainfalls. The mulberry crop which was grown both under surface and drip irrigation, on an average required 16.7 ha.cm of water with a WUE of 39 $\mathrm{Kg}$ cocoons/ha.cm. Among vegetables the tomato crop could utilize only 35 ha.cm (Drip irrigation) of water with a WUE of $1866 \mathrm{~kg} / \mathrm{ha} . \mathrm{cm}$. Cauliflower requiring about 22 ha.cm (Drip irrigation) with a WUE of $2034 \mathrm{~kg} / \mathrm{ha} . \mathrm{cm}$. Less WUE in case of cauliflower may be attributed to 3 per cent mortality of saplings in the early stages. Coriander grown as greens required 25 ha.cm with a WUE of 1600 bundles/ha.cm. While red gram (vegetable) required 33.5 ha.cm with a WUE of 239 $\mathrm{kg} / \mathrm{ha} . \mathrm{cm}$. Field beans grown as pure crop on an area of 1 ha under rainfed condition could utilize 28 ha.cm of water with and a WUE of $250 \mathrm{~kg} / \mathrm{ha} . \mathrm{cm}$. The findings of the present investigation are in agreement with the facts of (Anon, 2006) in increasing the crop yield and drip irrigation revolution will go a long way in creating perfect water use discipline in the state and help to reap advantages like Israel.

Table 2: Conveyance efficiency of open channel and buried pipe system

\begin{tabular}{|c|c|c|c|c|c|}
\hline \multicolumn{3}{|c|}{ Open channel } & \multicolumn{3}{|c|}{ Pipe system } \\
\hline$\Xi$ & $\Xi$ & خે & \multirow{5}{*}{ 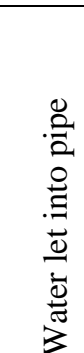 } & \multirow{5}{*}{ 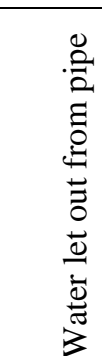 } & \multirow{5}{*}{ 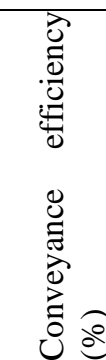 } \\
\hline$\stackrel{乛}{\nexists}$ & $\stackrel{\stackrel{O}{\Xi}}{.}$ & $\stackrel{\frac{U}{U}}{\mathscr{U}}$ & & & \\
\hline & $\Xi$ & & & & \\
\hline$\underline{\Xi}$ & & $\ddot{\Xi}$ & & & \\
\hline 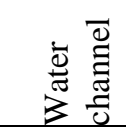 & 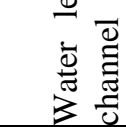 & $\stackrel{0}{0}$ & & & \\
\hline 16 & 8.8 & 55 & 3.3 & 3.1 & 93 \\
\hline 16 & 9.76 & 61 & 3.3 & 3.2 & 97 \\
\hline 16 & 11.52 & 72 & 3.3 & 3.2 & 97 \\
\hline 16 & 11.52 & 72 & 3.3 & 3.1 & 93 \\
\hline 16 & 11.03 & 69 & 3.3 & 3.2 & 97 \\
\hline Average & 10.81 & 67 & 3.7 & 3.18 & 95.4 \\
\hline
\end{tabular}

Table 3: Water use efficiency ( $\mathrm{kg} / \mathrm{ha} . \mathrm{cm})$ for the years 2003 2008

\begin{tabular}{|c|c|c|c|c|c|}
\hline Crop & 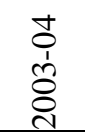 & 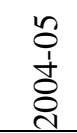 & 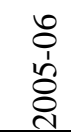 & 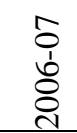 & \begin{tabular}{l}
$\infty$ \\
0 \\
1 \\
$\hat{0}$ \\
\multirow{2}{1}{}
\end{tabular} \\
\hline Paddy & 18.5 & 20.5 & 30.7 & 122 & 80.6 \\
\hline Ragi & 67 & 78 & 46.4 & 87.5 & 103.85 \\
\hline Jowar & 45 & - & - & - & - \\
\hline Betel vine & 1.2 & 1.2 & 1.35 & 3.5 & - \\
\hline
\end{tabular}




\begin{tabular}{|l|l|l|l|l|l|} 
Mulberry (Cocoons) & 13 & 13 & 25 & 42.5 & 39 \\
\hline Cauliflower & - & 652 & - & 2250 & 2034 \\
\hline Capsicum & - & - & 158 & 625 & - \\
\hline Chillies & - & - & 105 & - & - \\
\hline Radish & - & - & - & 888 & - \\
\hline Tomato & - & - & 562 & 1857 & 1866 \\
\hline Cabbage & - & - & 1661 & - & - \\
\hline Coriander & - & - & - & - & 1600 \\
\hline Red gram & - & - & - & - & 239 \\
\hline Field bean & - & - & - & - & 250 \\
\hline
\end{tabular}

\section{CONCLUSIONS}

The conveyance efficiency of open channel and under buried pipe system indicated that the conveyance efficiency of water was comparatively highest in underground pipe system as against open channel by recording 93 to 97 percent and 55 to 72 percent respectively. The effect of on-demand water supply and efficient irrigation systems has shown significant change in WUE in Chunchadenahalli tank command area. During kharif 2003, the WUE of $18.5 \mathrm{~kg} / \mathrm{ha} . \mathrm{cm}$ and $13.0 \mathrm{~kg} / \mathrm{ha} . \mathrm{cm}$ has been recorded in paddy and mulberry respectively. However, during 2007 the same crops recorded the WUE of 88.12 and $39 \mathrm{~kg} / \mathrm{ha}$. cm in paddy and mulberry respectively.

The water use efficiency based on the total water consumed and the yield obtained indicated that paddy crop grown under SRI (on and off) method of paddy cultivation consumed on an average of about 86.6 ha. $\mathrm{cm}$ of water with a water use efficiency of $80.6 \mathrm{~kg} / \mathrm{ha}$. $\mathrm{cm}$. While transplanted ragi crop recorded on an average 31.7 ha. $\mathrm{cm}$, with a water use efficiency of $110 \mathrm{~kg} / \mathrm{ha} . \mathrm{cm}$, the rainfed ragi with 24.2 ha.cm of water with a WUE of $97.7 \mathrm{q} / \mathrm{ha} . \mathrm{cm}$. The mulberry crop which was grown both under surface and drip irrigation, on an average required 16.7 ha.cm of water with a WUE of $39 \mathrm{~kg}$ cocoons/ha.cm. Among vegetables the tomato crop could utilize only 35 ha.cm (Drip irrigation) of water with a WUE of $1866 \mathrm{~kg} / \mathrm{ha} . \mathrm{cm}$

\section{ACKNOWLEDGEMENTS}

The authors are very much thankful to Sri M. Madan Gopal, Sri G. V. Krishna Rau and Dr. P. Bore Gowda, IAS Officer, Former Directors of JSYS, Govt. of Karnataka, Bangalore for extending the financial support to carry out this research work.

\section{REFERENCES}

[1]. Anon (2002) Central Ground Water Board Manual, Published by Govt. of India, New Delhi.

[2]. Campbell D.E. (1984). Pipe distribution systems in ground water development Agricultural Administration Vol.16, pp. 209-227

[3]. Chowdegowda M. (2003). All India Seminar on Emerging Trends in Micro-Irrigation for Efficient Water Management" December 26-27, 2003

[4]. James B.K. and WTCER (1998). Proceedings of the National Seminar on Micro-Irrigation Research in India: Status and Perspectives for the 21st Century, Bhubaneswar. [5]. Murthy, V.V.N. (2002). Text Book of Land and Water Management Engineering, Third Edition Kalyani Publishers [6]. Paliniswamy K and Ester K.W. (2000). Tank Irrigation in 21st Century, What next?" Discovery publication House, New Delhi

[7]. Radhakrisha, A. R (2012) On-demand water supply through buried pipe system for efficient irrigation - A Case Study. Ph.D Thesis submitted to Bangalore University, Bangalore.

[8]. Raju, K.V., Kranth, G. K., Bhende, M.J., Rajasekhar, D and Gayathridevi, K.G. (2003). Rejuvenating Tanks - A Socio Ecological Approach, Books for Change, Bangalore

[9]. Reddi Sankara G.H. And Reddy Yellamanada, (2003).Efficient Use of Irrigation Water" Kalyani Publication

\section{BIOGRAPHIES}

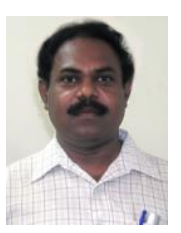

Dr. A. R. Radhakrisha graduated in Civil Engineering (1986) from University of Mysore and MSc(1999) from University of Agricultural Sciences, Bangalore and obtained Ph.D(2012) from Bangalore University. Presently he is working as Assistant professor in the Department of Agricultural Engineering, GKVK, UAS, Bangalore.

Dr. A. S. Ravikumar graduated in Civil Engineering (1991) from University of Mysore and M.Tech (1994) from KREC, Surathkal and obtained Ph.D (2001) from Indian Institute of Science, Bangalore. He has completed three major research projects funded by the DST, RESPOND and MOEF, Govt. of India and presently working as Team Leader and Regional Manager for the European Union funded Collaborative SIRIUS Project. He has guided 3 Ph.D and 3 are working for their Ph.D on Water Resource Engineering 